\title{
Serum Zonulin Levels and Social Cognition in Children with Attention Deficit Hyperactivity Disorder
}

\author{
Dikkat Eksikliği Hiperaktivite Bozukluğu olan Çocuklarda Serum Zonulin Düzeyleri ve Sosyal \\ Biliş̧
}

\author{
Nihal YURTERI' ${ }^{1}$ \\ (i) 0000-0002-4681-2210 \\ İbrahim Ethem ŞAHIN ${ }^{2}$ \\ (1) 0000-0003-3745-7015
}

\begin{abstract}
${ }^{1}$ Düzce University Medical Faculty Department of Child and Adolescent Psychiatry, Düzce, Turkey

${ }^{2}$ Düzce University Medical Faculty Department of Clinical Biochemistry, Düzce, Turkey
\end{abstract}

\section{Corresponding Author Sorumlu Yazar Nihal YURTERI yurterinihal@gmail.com}

Received / Gelis Tarihi : 12.08 .2020 Accepted / Kabul Tarihi : 18.11.2020 Available Online /

Çevrimiçi Yayın Tarihi : 25.12.2020

\begin{abstract}
Aim: Alterations in gut-brain axis of patients with attention deficit hyperactivity disorder (ADHD) have been indicated in recent studies. The aim of this study was to determine whether serum level of zonulin, considered to be a regulator of permeability in both gut-blood and blood-brain barriers, was associated with ADHD symptoms, and to evaluate the relationship between zonulin and social cognition in children with ADHD.

Material and Methods: Serum level of zonulin was analyzed by enzyme-linked immunosorbent assay (ELISA) in 40 treatment-naive children with ADHD, and age and gender matched 40 healthy children as control group. DuPaul ADHD Rating Scale was used for ADHD symptoms and reading the mind in the eyes test (RMET) was administered by the clinician to examine the social cognitive abilities.

Results: We found that serum zonulin levels were significantly higher in ADHD group compared to control group $(\mathrm{p}=0.010)$. Also, children with ADHD have significantly lower RMET scores $(\mathrm{p}=0.007)$. Furthermore, we found statistically significant positive correlations between serum zonulin levels and ADHD symptoms $(p<0.001)$ and a negative correlation between serum zonulin levels and RMET scores ( $\mathrm{p}=0.001)$ in ADHD group.

Conclusion: The present study is the first to evaluate whether there is a relationship between serum zonulin levels and social cognition in children with ADHD. The results of our study indicate that zonulin may be associated with ADHD and social cognition. Further studies with larger samples are required to determine the role of zonulin in ADHD.
\end{abstract}

Keywords: Attention deficit hyperactivity disorder; zonulin; social cognition; gut-brain axis.

\section{ÖZ}

Amaç: Son çalışmalarda dikkat eksikliği hiperaktivite bozukluğu (DEHB) tanılı hastaların bağırsak-beyin eksenindeki değişiklikler belirtilmiştir. Bu çalışmanın amacı, hem bağırsakkan hem de kan-beyin bariyerlerinde geçirgenliği düzenlemek için bir modülatör olarak kabul edilen zonulinin serum düzeyinin DEHB tanılı çocuklarda DEHB belirtileriyle ilişkili olup olmadığını belirlemek ve zonulin ile sosyal biliş arasında bir ilişki olup olmadığını değerlendirmektir.

Gereç ve Yöntemler: Zonulinin serum düzeyi, tedavi görmemiş 40 DEHB tanılı çocukta ve kontrol grubu olarak yaş ve cinsiyet yönünden eşleştirilmiş 40 sağlıklı çocukta enzime bağlı immünosorbent testi (enzyme-linked immunosorbent assay, ELISA) kullanılarak analiz edilmiştir. DEHB belirtileri, DuPaul DEHB Derecelendirme Ölçeği ile puanlanmış ve sosyal bilişsel becerileri incelemek için ise klinisyen tarafından gözlerden zihin okuma testi (reading the mind in the eyes test, RMET) uygulanmıştır.

Bulgular: DEHB grubunda serum zonulin düzeyleri kontrol grubuna göre anlamlı olarak yüksek olarak bulunmuştur ( $\mathrm{p}=0.010)$. Ayrıca, DEHB tanılı çocukların RMET puanları önemli ölçüde düşük bulunmuştur $(\mathrm{p}=0.007)$. Ek olarak, DEHB grubunda serum zonulin düzeyleri ile DEHB semptomları arasında istatistiksel olarak anlamlı pozitif korelasyon $(\mathrm{p}<0.001)$ ve serum zonulin düzeyleri ile RMET skorları arasında ise negatif korelasyon $(\mathrm{p}=0.001)$ bulunmuştur. Sonuç: Bu çalışma, DEHB tanılı çocuklarda serum zonulin düzeyleri ile sosyal biliş arasında bir ilişki olup olmadığını değerlendiren ilk çalışmadır. Çalışmamızın sonuçları, zonulinin DEHB ve sosyal biliș ile ilișkili olabileceğini göstermektedir. Zonulinin DEHB'deki rolünü belirlemek için daha büyük örneklemlerle yapılacak ileri çalışmalara ihtiyaç vardır.

Anahtar kelimeler: Dikkat eksikliği hiperaktivite bozukluğu; zonulin; sosyal biliş; bağırsakbeyin ekseni. 


\section{INTRODUCTION}

Attention deficit hyperactivity disorder (ADHD) is the most prevalent neurodevelopmental disorder (1-3) and characterized by developmentally inappropriate symptoms of inattention, hyperactivity and impulsivity (4).

Social cognition is considered to be essential for successful social interaction and defined as the ability to understand other's mind and feelings $(5,6)$. In addition to core symptoms of ADHD, it has been indicated that children with ADHD have difficulty in social cognitive abilities which is supposed to be mostly interpreted in the contex of fronto-striatal dysfunction (6-9). In a recent meta-analysis, performance of individuals with ADHD on social cognition was described to lie intermediate between autistic spectrum disorders (ASD) and healthy controls (7). Interestingly, indicating another overlapping aspect in ASD and ADHD, the gut microbiota and gut-brain axis has also been identified to be altered in patients with both ASD $(10,11)$ and ADHD $(12,13)$. Gut-brain axis is considered to involve the bi-directional communication between the gastrointestinal and central nervous systems (14). Zonulin (pre-haptoglobin 2) is known to be a modulator for regulator of permeability in gut-blood and blood-brain barriers via intercellular tight-junctions $(15,16)$. Zonulin is considered to increase permeability of the small intestine and to contribute to the intestinal immunity (17). Furthermore, zonulin has been described to be associated with inflammation and autoimmunity $(18,19)$, ASD (20) and ADHD (21). In addition, serum zonulin has been found to be related to social responsiveness (21).

We aimed to examine serum levels of zonulin and to explore whether there is an association between serum levels of zonulin and social cognition in treatment-naive children with ADHD. We have encountered no study investigating serum levels of zonulin and social cognition in children with ADHD.

\section{MATERIAL AND METHODS \\ Participants}

This research was carried out at the child and adolescent psychiatry outpatient clinic of Düzce University Medical Faculty. Based on zonulin levels found in a similar study in literature (20), the minimum sample size was calculated as 32 , with $95 \%$ confidence level and $80 \%$ power. Simple random sampling method was used in sample selection. The research group consisted of 40 treatment-naive children aged between 8-12 years old diagnosed with ADHD, and age-gender matched 40 healthy children admitted to the child psychiatry outpatient clinic without any psychopathology. Diagnoses and comorbidities were determined through clinical examination based on "Diagnostic and Statistical Manual of Mental Disorders (DSM 5)" and the Interview Schedule for "Affective Disorders and Schizophrenia for School-Age ChildrenPresent and Lifetime Version (Kiddie-SADS-PL)", and children with exclusion criteria were excluded from the study. Exclusion criteria for the case group were clinically mental retardation, autism, medical comorbidities, comorbid psychopathologies except oppositional defiant disorder (ODD), taking medication, having an infection history for the last month. Exclusion criteria for the control group were psychiatric diseases, chronic physical diseases and having an infection history for the last month. BMI of all subjects, calculated according to BMI percentiles of World Health Organization, were found to be within normal range. All of the children gave verbal assent and parents provided informed consent. The study was performed in accordance with the ethical standards established in the Declaration of Helsinki. Medical Ethics Committee of Düzce University approved the study (approval date: 04.03.2019, number: 2019/38).

\section{Measures}

1. Kiddie Schedule for Affective Disorders and Schizophrenia for School Age Children-Present and Lifetime Version (K-SADS-PL) Turkish: This interview was developed (22) to evaluate present and lifetime psychopathology in children and adolescents and Turkish translation was also conducted $(23,24)$.

2. Attention Deficit/Hyperactivity Disorder-Rating ScaleDuPaul (ADHD-RS): This scale evaluates ADHD symptoms according to DSM-IV criteria and contains 4point Likert type 18-item (25). The scale had been used in Turkish children with ADHD (26-28).

3. Reading the Mind in the Eyes Test (RMET): RMET is designed to test comprehension of other's mental states by looking at eye expression (29-32). It was created by BaronCohen et al. (29) in 1997, and a revised form was published in 2001 (30). Turkish translation for children was performed by Girli (31).

\section{Blood Sampling and Analysis}

Blood samples of all participants were drawn from antecubital vein between 8:00 and 10:00 a.m. after an overnight fasting. Blood samples were centrifuged at 4,000 rpm for $5 \mathrm{~min}$ and the serum was stored in $-80{ }^{\circ} \mathrm{C}$ until analysis time. Serum levels of zonulin were measured using commercial enzyme-linked immunosorbent assay (ELISA) kits according to the protocols of the manufacturers (Elabscience, USA, cat. No: E-EL- H5560). Analysis results were expressed in $\mathrm{ng} / \mathrm{mL}$.

\section{Statistical Analyses}

SPSS v.21 was used for the analyses. Relationships between dichotomous variables were assessed with Pearson chi-square test. The distribution of numerical variables was examined by Shapiro-Wilk normality test. Differences of continuous variables between groups, were analyzed using Mann-Whitney $U$ test. The correlation between serum zonulin levels and the psychometric test scores was evaluated by Spearman's correlation analyses. Descriptive statistics were given as frequency, percentage, and median, interquartile range and minimum-maximum. A p value of 0.05 was accepted as significance level.

\section{RESULTS}

The mean age was $115.28 \pm 15.47$ and $120.38 \pm 15.49$ months, for ADHD group and the control group, respectively. Majority of the subjects were male, $80 \%(n=32)$ in ADHD and $75 \%(n=30)$ in control groups. Because we matched ADHD and control groups according to gender and age, ADHD and control groups did not differ significantly according to gender $(p=0.592)$ and age $(p=0.124)$. Children in ADHD group had significantly higher scores in terms of Du Paul ADHD-RS ( $\mathrm{p}<0.001)$ and lower scores in terms of RMET $(p=0.007)$ compared to children in the control group. Zonulin levels were found to be significantly higher in ADHD group ( $\mathrm{p}=0.010$, Table 1). 
Table 1. Comparison of clinical parameters in ADHD and control groups

\begin{tabular}{lccc}
\hline & ADHD $(\mathbf{n}=\mathbf{4 0})$ & Control (n=40) & $\mathbf{p}$ \\
\hline DuPaul ADHD-RS Inattentive score & $16(2)[13-19]$ & $3(2)[1-4]$ & $<\mathbf{0 . 0 0 1}$ \\
DuPaul ADHD-RS Hyperactivity score & $13.5(4)[12-18]$ & $2(2)[0-3]$ & $<\mathbf{0 . 0 0 1}$ \\
DuPaul ADHD-RS Total score & $29(6)[26-35]$ & $5(2)[2-7]$ & $<\mathbf{0 . 0 0 1}$ \\
RMET & $15(2)[13-18]$ & $16(2)[13-20]$ & $\mathbf{0 . 0 0 7}$ \\
Zonulin & $97.62(58.92)[1.71-340.71]$ & $68.27(56.41)[1.81-199.88]$ & $\mathbf{0 . 0 1 0}$ \\
\hline
\end{tabular}

ADHD: attention deficit hyperactivity disorder, DuPaul ADHD-RS: attention deficit/hyperactivity disorder-rating scale, RMET: reading the mind in the eyes test, descriptive statistics were given as median (interquartile range) [minimum-maximum]

In ADHD group, the correlations between zonulin levels and age, RMET and DuPaul ADHD-RS (inattentive, hyperactivity, total) scores were examined by Spearman's correlation analyses. Although there was no correlation between zonulin level and age $(\mathrm{p}=0.937)$, zonulin level was found to be significantly negatively correlated with RMET score $(\mathrm{r}=-0.498, \mathrm{p}=0.001)$ and positively correlated with inattentive $(\mathrm{r}=0.558, \mathrm{p}<0.001)$, hyperactivity $(\mathrm{r}=0.704, \mathrm{p}<0.001)$, and total $(\mathrm{r}=0.697, \mathrm{p}<0.001)$ scores of DuPaul ADHD-RS (Table 2).

Table 2. Correlations between clinical parameters and serum zonulin levels in ADHD group

\begin{tabular}{lcccc}
\hline & \multicolumn{2}{c}{ Zonulin } & \multicolumn{2}{c}{ RMET } \\
\cline { 2 - 5 } & $\mathbf{r}$ & $\mathbf{p}$ & $\mathbf{r}$ & $\mathbf{p}$ \\
\hline Zonulin & & & -0.498 & $\mathbf{0 . 0 0 1}$ \\
RMET & -0.498 & $\mathbf{0 . 0 0 1}$ & & \\
DuPaul-IA & 0.558 & $<\mathbf{0 . 0 0 1}$ & -0.467 & $\mathbf{0 . 0 0 2}$ \\
DuPaul-HA & 0.704 & $<\mathbf{0 . 0 0 1}$ & -0.643 & $<\mathbf{0 . 0 0 1}$ \\
DuPaul-Total & 0.697 & $<\mathbf{0 . 0 0 1}$ & -0.611 & $<\mathbf{0 . 0 0 1}$ \\
\hline
\end{tabular}

ADHD: attention deficit hyperactivity disorder, DuPaul ADHD-RS: attention deficit/hyperactivity disorder-rating scale, RMET: reading the mind in the eyes test, IA: inattentive, HA: hyperactivity

\section{DISCUSSION}

We evaluated serum level of zonulin in treatment-naive children with ADHD with respect to ADHD symptomatology and social cognition. We found increased serum zonulin levels in treatment-naive children with ADHD compared to healthy controls. Furthermore, we found positive correlations between serum zonulin levels and ADHD symptoms and negative correlations between zonulin levels and RMET scores.

In literature, there are two studies examining zonulin levels in ADHD (21,32). In one of those studies, conducted in children with ADHD, no significant difference was found between serum zonulin levels of ADHD and control groups (32). However, consistent with our findings, Özyurt et al. (21) reported that zonulin was associated with hyperactivity and social responsiveness in children with ADHD. Our results are also in the same line with the study reporting an association between social communication problems and serum zonulin levels in children with ASD (20). In detail, zonulin expression is considered to be regulated by systemic inflammation in addition to local enteric inflammation (33). Interestingly, biomarkers of subclinical inflammation, especially interleukin-6 (IL-6), have been proposed to regulate the gene expression of haptoglobulin-2 encoding zonulin protein $(34,35)$. IL-6 was reported to increase in individuals with both ASD (36) and ADHD (37). Considering all the results of the studies reporting zonulin increase in ASD (20) and ADHD (21), reported association between serum zonulin levels and social responsiveness (21) and mentioned findings in biomarker level together, we suggest that coinciding inflammatory processes might explain our finding of the association between serum zonulin levels and social cognition deficits in ADHD.

On the other hand, Özyurt et al. (21) posited that the relationship between zonulin and social problems in children with ADHD might be moderated by oxytocin functioning. This hypothesis was developed by authors based on preclinical studies showing changes in intestinal permeability with oxytocin (38) which was found to be correlated with social communication skills in ASD (39), and a clinical study reporting alterations in oxytocin functioning in children with ADHD and social deficits (40). Given the fact that social cognition is the fundamental step for social communication, altered oxytocin functioning might also be another mechanism explaining our finding of the relationship between serum zonulin levels and social cognition deficits in ADHD.

Alterations in zonulin levels have also been reported in autoimmune diseases (41), obesity (42), insulin resistance (34), type 1 and 2 diabetes (43-45), central nervous system diseases, chronic inflammatory diseases, cancers $(46,47)$ and psychiatric conditions such as anxiety, depression, acute stress provocation $(48,49)$. Furthermore, zonulin was also reported to be related to gut microbiota and dietary factors (50-52). We did not examine gut microbiota or dietary habits, however we excluded patients with medical comorbidities such as chronic inflammatory, immunological, endocrinological, allergic diseases and psychiatric comorbidities other than ODD, matched the groups according to age, gender and BMI and included only treatment- naive patients. We intended to increase the reliability of our results with this method.

Including only treatment-naive patients, excluding comorbidities with the K-SADS-PL, matching the groups in terms of age, gender and BMI are the strengths of this study. However, there are some limitations of this study. Firstly, the sample is consisted of relatively small number of patients. Secondly, we did not examine other factors such as gut microbiota and dietary habits. To evaluate social cognition in our study, we utilized one of the most frequently used tasks in social cognition research, known as RMET. RMET is known as an improved mind reading test that measures mentalization skills (29). However, an important limitation of this study is the lack of different measures reflecting social cognition skills in ADHD. 


\section{CONCLUSION}

In conclusion, the results of our study indicate that zonulin may be associated with ADHD and social cognition deficits in children with ADHD. Further comprehensive studies with larger samples are required to determine the role of zonulin in ADHD.

Ethics Committee Approval: The study was approved by the Ethics Committee of Düzce University Faculty of Medicine $(04.03 .2019,38)$.

Conflict of Interest: None declared by the authors.

Financial Disclosure: None declared by the authors.

Acknowledgements: None declared by the authors.

\section{REFERENCES}

1. Polanczyk GV, Salum GA, Sugaya LS, Caye A, Rohde LA. Annual research review: A meta-analysis of the worldwide prevalence of mental disorders in children and adolescents. J Child Psychol Psychiatry. 2015;56(3):345-65.

2. Wittchen HU, Jacobi F, Rehm J, Gustavsson A, Svensson M, Jönsson B, et al. The size and burden of mental disorders and other disorders of the brain in Europe 2010. Eur Neuropsychopharmacol. 2011;21(9):655-79.

3. Willcutt EG. The prevalence of DSM-IV attentiondeficit/hyperactivity disorder: a meta-analytic review. Neurotherapeutics. 2012;9(3):490-9.

4. American Psychiatric Association (APA). Diagnostic and statistical manual of mental disorders (DSM-5). 5th ed. Washington DC: American Psychiatric Association Publishing; 2013.

5. Uekermann J, Daum I. Social cognition in alcoholism: a link to prefrontal cortex dysfunction? Addiction. 2008;103(5):726-35.

6. Uekermann J, Kraemer M, Abdel-Hamid M, Schimmelmann BG, Hebebrand J, Daum I, et al. Social cognition in attention-deficit hyperactivity disorder (ADHD). Neurosci Biobehav Rev. 2010;34(5):734-43.

7. Bora E, Pantelis C. Meta-analysis of social cognition in attention-deficit/hyperactivity disorder (ADHD): comparison with healthy controls and autistic spectrum disorder. Psychol Med. 2016;46(4):699-716.

8. Özbaran B, Kalyoncu T, Köse S. Theory of mind and emotion regulation difficulties in children with ADHD. Psychiatry Res. 2018;270:117-22.

9. Şahin B, Karabekiroğlu K, Bozkurt A, Usta MB, Aydın M, Çobanoğlu C. The relationship of clinical symptoms with social cognition in children diagnosed with attention deficit hyperactivity disorder, specific learning disorder or autism spectrum disorder. Psychiatry Investig. 2018;15(12):1144-53.

10. Finegold SM. State of the art; microbiology in health and disease. Intestinal bacterial flora in autism. Anaerobe. 2011;17(6): 367-8.

11. de Theije CG, Wu J, da Silva SL, Kamphuis PJ, Garssen J, Korte SM, et al. Pathways underlying the gut-to-brain connection in autism spectrum disorders as future targets for disease management. Eur J Pharmacol 2011;668(Suppl 1):s70-80.
12. Cenit MC, Nuevo IC, Codoñer-Franch P, Dinan TG, Sanz Y. Gut microbiota and attention deficit hyperactivity disorder: new perspectives for a challenging condition. Eur Child Adolesc Psychiatry. 2017;26(9):1081-92.

13. Dam SA, Mostert JC, Szopinska-Tokov JW, Bloemendaal M, Amato M, Arias-Vasquez A. The role of the gut-brain axis in attention-deficit/hyperactivity disorder. Gastroenterol Clin North Am. 2019;48(3):407-31.

14. Liu L, Zhu G. Gut-brain axis and mood disorder. Front Psychiatry. 2018;9:223.

15. Fasano A. Regulation of intercellular tight junctions by zonula occludens toxin and its eukaryotic analogue zonulin. Ann N Y Acad Sci. 2000;915:214-22.

16. Fasano A. Zonulin and its regulation of intestinal barrier function: the biological door to inflammation, autoimmunity, and cancer. Physiol Rev. 2011;91(1):151-75.

17. El Asmar R, Panigrahi P, Bamford P, Berti I, Not T, Coppa GV, et al. Host-dependent zonulin secretion causes the impairment of the small intestine barrier function after bacterial exposure. Gastroenterology. 2002;123(5):1607-15.

18. Fasano A. Zonulin, regulation of tight junctions, and autoimmune diseases. Ann N Y Acad Sci. 2012;1258(1):25-33.

19. Asbjornsdottir B, Snorradottir H, Andresdottir E, Fasano A, Lauth B, Gudmundsson LS, et al. Zonulindependent intestinal permeability in children diagnosed with mental disorders: A systematic review and meta-analysis. Nutrients. 2020;12(7):1982.

20. Esnafoglu E, Cirrık S, Ayyıldız SN, Erdil A, Yurdakul Ertürk EY, Daglı A, et al. Increased serum zonulin levels as an intestinal permeability marker in autistic subjects. J Pediatr. 2017;188:240-4.

21. Özyurt G, Öztürk Y, Appak YÇ, Arslan FD, Baran M, Karakoyun I, et al. Increased zonulin is associated with hyperactivity and social dysfunctions in children with attention deficit hyperactivity disorder. Compr Psychiatry. 2018;87:138-42.

22. Kaufman J, Birmaher B, Brent D, Rao U, Flynn C, Moreci P, et al. Schedule for affective disorders and schizophrenia for school-age children-present and lifetime version (K-SADS-PL): initial reliability and validity data. J Am Acad Child Adolesc Psychiatry. 1997;36(7):980-8.

23. Gökler B, Ünal F, Pehlivantürk B, Çengel Kültür E, Akdemir D, Taner Y. Reliability and validity of schedule for affective disorders and schizophrenia for school age children-present and lifetime versionTurkish version (K-SADS-PL-T). Turk J Child Adolesc Ment Health. 2004;11(3):109-16.

24. Ünal F, Öktem F, Çetin Çuhadaroğlu F, Çengel Kültür SE, Akdemir D, Foto Özdemir D, et al. Reliability and validity of the schedule for affective disorders and schizophrenia for school-age children-present and lifetime version, DSM-5 November 2016-Turkish adaptation (K-SADS-PL-DSM-5-T). Turk Psikiyatri Derg. 2019;30(1):42-50.

25. DuPaul GJ, Power TJ, Anastopoulos AD, Reid R. ADHD rating scale IV: checklists, norms and clinical interpretation. New York: Guilford Press; 1998. 
26. Yurteri N, Şahin İE, Tufan AE. Altered serum levels of vascular endothelial growth factor and glial-derived neurotrophic factor but not fibroblast growth factor-2 in treatment-naive children with attention deficit/hyperactivity disorder. Nord J Psychiatry. 2019;73(4-5):302-7.

27. Akay AP, Resmi H, Güney SA, Erkuran HÖ, Özyurt G, Sargin E, et al. Serum brain-derived neurotrophic factor levels in treatment-naive boys with attentiondeficit/hyperactivity disorder treated with methylphenidate: an 8-week, observational pretest-posttest study. Eur Child Adolesc Psychiatry. 2018;27(1):127-35.

28. Yurteri N, Şahin İE. Decreased serum levels of total and high molecular weight adiponectin in treatment-naive children with ADHD. Anadolu Psikiyatri Derg. 2020;21(6):633-40.

29. Baron-Cohen S, Jolliffe T, Mortimore C, Robertson M. Another advanced test of theory of mind: evidence from very high functioning adults with autism or asperger syndrome. J Child Psychol Psychiatry. 1997;38(7):813-22.

30. Baron-Cohen S, Wheelwright S, Hill J, Raste Y, Plumb I. The "reading the mind in the eyes" test revised version: a study with normal adults, and adults with Asperger syndrome or high-functioning autism. J Child Psychol Psychiatry. 2001;42(2):241-51.

31. Girli A. Psychometric properties of the Turkish child and adult form of "reading the mind in the eyes test". Psychology. 2014;5(11):1321-37.

32. Aydoğan Avşar P, Işık Ü, Aktepe E, Kılıç F, Doğuç DK, Büyükbayram HI. Serum zonulin and claudin-5 levels in children with attention-deficit/hyperactivity disorder. Int J Psychiatry Clin Pract. 2020;[Epub ahead of print]. doi: 10.1080/13651501.2020.1801754.

33. Küme T, Acar S, Tuhan H, Çatlı G, Anık A, Gürsoy Çalan Ö, et al. The relationship between serum zonulin level and clinical and laboratory parameters of childhood obesity. J Clin Res Pediatr Endocrinol. 2017;9(1):31-8.

34. Moreno-Navarrete JM, Sabater M, Ortega F, Ricart W, Fernández-Real JM. Circulating zonulin, a marker of intestinal permeability, is increased in association with obesity-associated insulin resistance. PLoS One. 2012;7(5):e37160.

35. Brock M, Trenkmann M, Gay RE, Gay S, Speich R, Huber LC. MicroRNA-18a enhances the interleukin-6-mediated production of the acute-phase proteins fibrinogen and haptoglobin in human hepatocytes. J Biol Chem 2011;286(46):40142-50.

36. Emanuele E, Orsi P, Boso M, Broglia D, Brondino N, Barale F, et al. Low-grade endotoxemia in patients with severe autism. Neurosci Lett. 2010;471(3):162-5.

37. Cortese S, Angriman M, Comencini E, Vincenzi B, Maffeis C. Association between inflammatory cytokines and ADHD symptoms in children and adolescents with obesity: A pilot study. Psychiatry Res 2019;278:7-11.

38. Welch MG, Margolis KG, Li Z, Gershon MD. Oxytocin regulates gastrointestinal motility, inflammation, macromolecular permeability, and mucosal maintenance in mice. Am J Physiol Gastrointest Liver Physiol. 2014;307(8):G848-62.

39. Taurines R, Schwenck C, Lyttwin B, Schecklmann M, Jans $\mathrm{T}$, Reefschläger L, et al. Oxytocin plasma concentrations in children and adolescents with autism spectrum disorder: correlation with autistic symptomatology. Atten Defic Hyperact Disord. 2014;6(3):231-9.

40. Demirci E, Ozmen S, Kilic E, Oztop DB. The relationship between aggression, empathy skills and serum oxytocin levels in male children and adolescents with attention deficit and hyperactivity disorder. Behav Pharmacol. 2016;27(8):681-8.

41. Fasano A, Not T, Wang W, Uzzau S, Berti I, Tommasini A, et al. Zonulin, a newly discovered modulator of intestinal permeability, and its expression in coeliac disease. Lancet. 2000;355(9214):1518-9.

42. Zak-Gołąb A, Kocełak P, Aptekorz M, Zientara M, Juszczyk L, Martirosian G, et al. Gut microbiota, microinflammation, metabolic profile, and zonulin concentration in obese and normal weight subjects. Int $\mathbf{J}$ Endocrinol. 2013;2013:674106.

43. Zhang D, Zhang L, Zheng Y, Yue F, Russell RD, Zeng Y. Circulating zonulin levels in newly diagnosed Chinese type 2 diabetes patients. Diabetes Res Clin Pract. 2014;106(2):312-8.

44. Jayashree B, Bibin YS, Prabhu D, Shanthirani CS, Gokulakrishnan K, Lakshmi BS, et al. Increased circulatory levels of lipopolysaccharide (LPS) and zonulin signify novel biomarkers of proinflammation in patients with type 2 diabetes. Mol Cell Biochem. 2014;388(1-2):203-10.

45. Sapone A, de Magistris L, Pietzak M, Clemente MG, Tripathi A, Cucca F, et al. Zonulin upregulation is associated with increased gut permeability in subjects with type 1 diabetes and their relatives. Diabetes. 2006;55(5):1443-9.

46. Fasano A. Intestinal permeability and its regulation by zonulin: diagnostic and therapeutic implications. Clin Gastroenterol Hepatol. 2012;10(10):1096-100.

47. Sturgeon C, Fasano A. Zonulin, a regulator of epithelial and endothelial barrier functions, and its involvement in chronic inflammatory diseases. Tissue Barriers. 2016;4(4):e1251384.

48. Stevens BR, Goel R, Seungbum K, Richards EM, Holbert $\mathrm{RC}$, Pepine CJ, et al. Increased human intestinal barrier permeability plasma biomarkers zonulin and FABP2 correlated with plasma LPS and altered gut microbiome in anxiety or depression. Gut. 2018;67(8):1555-7.

49. Linninge C, Jönsson P, Bolinsson H, Önning G, Eriksson $\mathrm{J}$, Johansson $\mathrm{G}$, et al. Effects of acute stress provocation on cortisol levels, zonulin and inflammatory markers in lowand high-stressed men. Biol Psychol. 2018;138:48-55.

50. Mörkl S, Lackner S, Meinitzer A, Mangge H, Lehofer M, Halwachs B, et al. Gut microbiota, dietary intakes and intestinal permeability reflected by serum zonulin in women. Eur J Nutr. 2018;57(8):2985-97.

51. Raftery T, Martineau AR, Greiller CL, Ghosh S, McNamara D, Bennett K, et al. Effects of vitamin D supplementation on intestinal permeability, cathelicidin and disease markers in Crohn's disease: Results from a randomised double-blind placebo-controlled study. United European Gastroenterol J. 2015;3(3):294-302.

52. Souza NC, Mendonca JN, Portari GV, Jordao Junior AA, Marchini JS, Chiarello PG. Intestinal permeability and nutritional status in developmental disorders. Altern Ther Health Med. 2012;18(2):19-24. 